\title{
Antibiotic residues
} in cow's milk

\author{
N. Mimoune ${ }^{*}$, S. Seddiki , R. Baazizi, I. E. Saboundji, R. Saidi, D. Khelef \\ and R. Kaidi
}

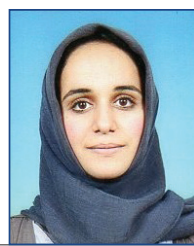

\section{Abstract}

Veterinary treatments, mainly antibiotics, used for therapeutic or prophylactic purposes in dairy cows, may be the cause of the presence of their residues in milk. This can have harmful consequences on animal and human health. To fully understand this problem, the present study aimed to evaluate the presence of antibiotic residues on 160 samples of cow's milk in the North Central region of Algeria, using two distinct microbiological techniques (acidification test and agar diffusion test) for two strains Bacillus stearothermophilus and Bacillus subtilis. The results showed antibiotic residue contamination in $18.12 \%$ of samples. Tetracycline and/or penicillin residues were responsible for the contamination of $90 \%$ of positive milk samples, while macrolide and/or aminoglycoside residues were only

detected in $6.66 \%$ of positive samples. The confirmation by the agar diffusion test of the 31 raw milk samples including 30 positive and one suspicious sample, analysed by the acidification test, showed a contamination rate of $90.32 \%$ for beta-lactams and/or tetracyclines (28 samples) and a contamination rate of $3.22 \%$ for aminoglycosides and/or macrolides (2 samples). The suspicious sample tested negative. The results of this study showed that the control and monitoring of antibiotics and their residues by collectors and in foods of animal origin are particularly important to ensure the safety of food of animal origin, and thus to protect the consumer.

Key words: residues; antibiotic; milk; cow; acidification test; agar diffusion test

\section{Introduction}

Milk is one of the most nutritious and complete foods. It is rich in high quality protein, providing all ten essential amino acids, fats especially essential fatty acids, and most minerals and vitamins. As a nutrient, milk plays a major role in the human diet, especially for children (Mahmoudi et al., 2013). Therefore, it must meet strict standards to ensure impeccable quality, both microbiologically and toxicologically, since it is a fragile product. Milk intended

\footnotetext{
Nora MIMOUNE*\#, (Corresponding author: nora.mimoune@gmail.com), National high school of veterinary medicine, Algiers, Bab-Ezzouar, Algeria, Institute of Veterinary Sciences, LBRA Laboratory, University of Blida 1, Algeria; Sara SEDDIKI ${ }^{\sharp}$, Faculty of Natural and Life Sciences and Earth and Universe Sciences, Mohamed El Bachir El Ibrahimi University, Bordj Bou Arréridj, Algeria; Ratiba BAAZIZI, Imad Eddine SABOUNDJI, Djamel KHELEF, National high school of veterinary medicine, Algiers, BabEzzouar, Algeria; Radhwane SAIDI, Department of Agronomic Sciences, Faculty of Sciences, Laboratory of Biological and Agronomic Sciences, University of Laghouat, Algeria; Rachid KAIDI, Institute of Veterinary Sciences, LBRA Laboratory, University of Blida 1, Algeria

\#These authors have contributed equally to this work
} 
for human consumption must therefore be free of any type of contamination, particularly medicinal (Pleadin and Samardžija, 2019). Unfortunately, the increasing and often irrational use of antibiotic products very often results in the presence of their residues.

Antibiotic residues are defined according to the European Union (EU) as "pharmacologically active substances (whether active principles, recipients, or degradation products) and their metabolites which remain in foodstuffs obtained from animals to which veterinary medicinal products in question has been administered" (Sachi et al., 2019). These residues can sometimes be a danger for the consumer by triggering rare allergic (Dewdney et al., 1991) and toxic (Perry et al., 1967) cases, or by promoting the emergence of a multi-resistant microflora, but above all, they may be the cause of significant disruption of the fermentation and maturation processes of dairy products such as yogurt, cheese and other milks (Ouslimani, 2008; Persoons, 2011; Mensah et al., 2014). Heat treatment of milk would allow for the elimination of only part of residues, since not all antibiotics have the same thermolability (Pilet and Toma, 1969). Faced with these risks, several countries have regulated the use of antibiotics and initiated the systematic control of raw milk before its use (Mensah et al., 2014). In Algeria, information on the extent of milk contamination with antibiotic residues is limited. It is in this context that we considered it interesting to carry out this study, which aimed to detect antibiotic residues in cow's milk and to gain a better understanding of the main families of antibiotics involved.

\section{Materials and Methods}

\section{Samples, study area and period}

This study examined a total of 160 samples collected in two regions in North Central Algeria (Boumerdes and
Algiers) from April to August 2019. All milk samples collected were from cows declared healthy by the farmer.

For each sample, a volume of $2 \times 40$ $\mathrm{mL}$ was collected in a sterile, leak-proof $50 \mathrm{~mL}$ bottle. After washing, drying and disinfection of teats, the first stream of milk was discarded and the sample was collected. The milk collected from each bottle corresponded was a mixture from all four udder quarters.

Samples were transported in a cooler with ice packs and frozen at $-20^{\circ} \mathrm{C}$ within 3 hours of collection. They were analysed within a month of collection at the HIDAOA (Hygiene and Inspection of Food of Animal Origin) laboratory of the Higher National Veterinary School of Algiers, Algeria. No break in the cold chain occurred during the study.

\section{Test microorganisms used}

Two test microorganisms were used to search for antibiotic residues by microbiological methods: Bacillus subtilis, ATCC6633 spore suspension and B. sterothermophilus Var. Calidolactis strain C953, obtained from NIVM (National Institute of Veterinary Medicine, Algiers, Algeria).

\section{Methods}

We adopted the official European method for the detection of antibiotic residues in milk (Commission Decision 91/180/EEC of 14 February 1991), applied in the European Union since 1 January 2002 (European Decision 91/180/EEC; EC Regulation $\mathrm{N}^{\circ} 1664 / 2006$ ).

Two techniques were successively carried out: acidification test (shows the possible inhibition of a strain of $B$. stearothermophilis var. calidolactis C 953 by the milk sample to be tested) and the confirmation test (corresponds to the realization of two agar diffusion tests, one with $B$. subtilis and the other with $B$. searothermophilus) as described by BenMahdi and Ouslimani (2009). 


\section{Acidification test}

This test normally allowed a first screening in the totality of the tested samples, seeking out possible inhibition of Bacillus stearothermophilus var. calidolactis C953. The test was declared positive when there is no acidification of the sample. Acidification usually results in coagulation of milk and a change in the colour indicator.

We performed revivification of the strains. This transplantation allowed us to obtain young strains of Bacillis subtilis and B. stearothermophilus.

The preparation of the milk sample to be tested was as follows: milk samples were thawed and homogenized and $2 \mathrm{~mL}$ of each sample was placed in a sterile test tube. Then, tubes were placed in a water bath at $80{ }^{\circ} \mathrm{C}$ for $10 \mathrm{~min}$, with the milk level at least $2 \mathrm{~cm}$ below the water level to eliminate natural inhibitors that can distort results. After that, samples were cooled to room temperature.

These prepared samples were then subject to analysis use:

Identify and number the tests tubes containing $2 \mathrm{~mL}$ of each cow's milk sample or $2 \mathrm{~mL}$ of the control $(+)$ milk or negative control $(-)$, place them on a rack required for the examination of cow's milk samples and controls.

- Under a Bunsen burner flame, remove the lid or cap;

- Add a volume of $0.1 \mathrm{~mL}$ test culture (see Annex 2) consisting of $10 \mathrm{~mL}$ B. stearothermophilus culture, $5 \mathrm{~mL}$ yeast extract $(10 \%)$ and $10 \mathrm{~mL}$ bromocresol purple $(0.25 \%)$;

- Add $0.2 \mathrm{~mL}$ trimethoprim;

- Place all tubes in an oven at $64^{\circ} \mathrm{C}$ for 2.5 hours;

- Remove the rack containing the tubes from the oven;

- Observe the appearance and colour of the sample and the controls.
Yellow coloration means that the milk is free of inhibiting substances such as antibiotic residues, while purple indicates the presence of antibiotic residues.

\section{Agar diffusion method}

This confirmation method requires the use of the two following species: $B$. stearothermophilus and B. subtilis. Only suspicious or positive samples should be submitted for confirmatory testing. It involves the use of an agar diffusion technique, characterized by the inhibition of the growth of the test organism by antibiotic residues that may be present in the milk.

The method consists of:

- Preparing 10 tubes of $9 \mathrm{~mL} \mathrm{0.9 \%}$ sterile saline solution.

- Proceed to the 10 in 10 dilution using a sterile pipette, take $1 \mathrm{~mL}$ of stock solution already prepared in the acidification test (reactivation of strains) to the first tube of the saline solution. Shake, then transfer $1 \mathrm{~mL}$ from the first tube to the second tube, then to the third tube and so on until the last dilution $10^{-1}$.

- Introduce $0.1 \mathrm{~mL}$ of each dilution (from $10^{-1}$ to $10^{-10}$ ) in each Petri dish, using two Petri dishes for each dilution.

- Introduce 15 to $20 \mathrm{~mL}$ nutrient agar.

- Mix the inoculum and culture medium, using figure-of-eight movements.

- Incubate at $30^{\circ} \mathrm{C}$ for B. subtilus and $55{ }^{\circ} \mathrm{C}$ for $B$. stearothermophilus for 24 hours;

- Colony count: after incubation, select boxes with a number of colonies between 30 and 300 CFU.

- Take the arithmetic mean of the counts between the two trials carried out with the same dilution.

- Calculate the number of colonyforming units per $\mathrm{mL}$ of the dilution (CFU/mL); 
- Multiply by the inverse of this dilution to get the number of bacteria per $1 \mathrm{~mL}$ of the mother suspension.

- The final loading of the stock solution in CFU/mL and estimated by averaging the concentrations obtained for the different dilutions.

For both strains, once the loading of the parent suspension has been determined, it is sufficient to calculate the dilution to be made in order to obtain a daughter suspension with a loading between 104 and 105 CFU per mL.

\section{Preparation of Petri dishes}

Bacillus subtilis

- Muller Hinton agar medium previously melted at $100^{\circ} \mathrm{C}$ and cooled to $55^{\circ} \mathrm{C}$.

- In front of the Bunsen burner, pour the Mueller Hinton medium into the Petri dishes and let it solidify.

- Using swabs, inoculate the surface of the Petri dishes with a suspension (104 to $105 \mathrm{CFU} / \mathrm{mL}$ ) of B. subtilis strain.

\section{Bacillus stearothermophilus}

- Muller Hinton agar medium previously melted at $100^{\circ} \mathrm{C}$ and cooled to $55^{\circ} \mathrm{C}$;

- In front of the Bunsen burner, the medium is inoculated by means of the liquid culture of $B$.

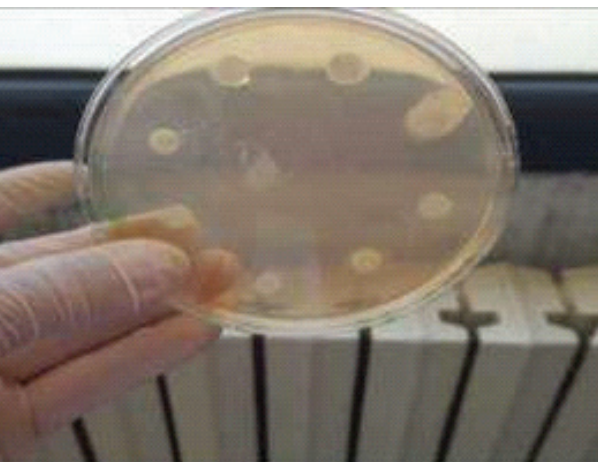

Figure 1. Example of the layout of the dish adopted during the confirmation test

sterothermophilus at a rate of one part of the latter to five parts of medium;

- They are mixed well;

- Pour the Mueller Hinton medium into the Petri dishes and let it solidify.

\section{Antibiotic discs layout plan}

Seven discs corresponding to seven milk samples to be analysed were deposited per petri dish, in addition to the control antibiotic disc. The eight discs are arranged in a circle $1 \mathrm{~cm}$ from the periphery of the dish and no disc was placed in the centre of the dish (Figure 1).

Table 1 lists the different families of antibiotics detected by inhibition of each of these two test microorganisms.

Table 1. Families of antibiotics detected by B. searothermophilus and B. subtilis in the confirmatory test

\begin{tabular}{|c|c|c|}
\hline Test microorganism & Antibiotic tested & Family of ATB \\
\hline \multirow{2}{*}{ Bacillus subtilis } & $\begin{array}{c}\text { Spiramycine } \\
\text { Erythromycine } \\
\text { Streptomycine }\end{array}$ & Macrolides \\
\hline Bacillus sterothermophilus & Penicillin $G$ & Aminoside \\
\hline & Tetracycline & Penicillin \\
\hline
\end{tabular}




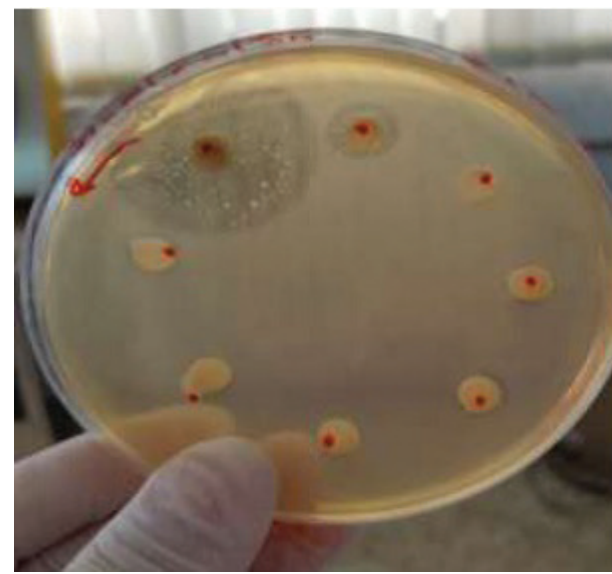

Figure 2. Inhibition zone

\section{Incubation and result reading}

The boxes were incubated at $55^{\circ} \mathrm{C}$ for B. sterothermophilus and $30^{\circ} \mathrm{C}$ for $B$. subtilis. After 24 hours of incubation, the results were read by checking the presence or absence of inhibition zones around the disc. Milk samples giving rise to inhibition zones of at least 10 $\mathrm{mm}$ in diameter were considered positive, i.e. containing antibiotics (Ben-Mahdi and Ouslimani, 2009; Larpent, 2013). The diameter of this inhibition zone was measured and reported for each sample tested positive (Figure 2).

\section{Statistical analysis}

Descriptive statistical analysis was performed using SPSS version 20 software. Chi-square test was realized

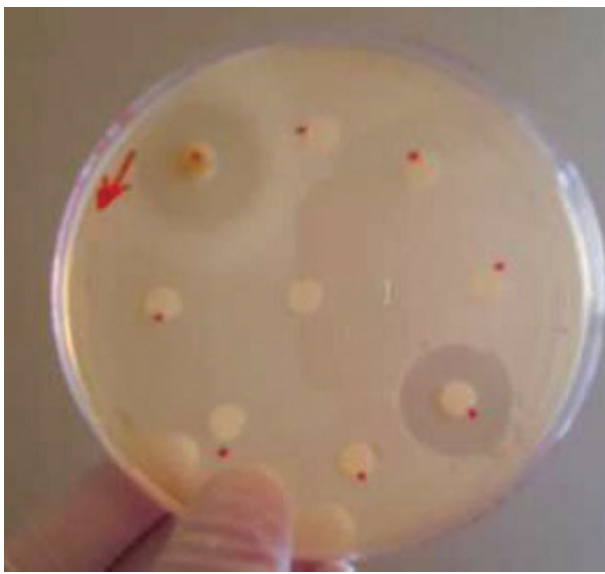

to analyse the different variances. Data were expressed as a percentage or mean. The results were considered significant at $P<0.05$.

\section{Results}

\section{Results of the search for antibiotic residues in cow's milk by the acidification test}

The overall result of the search for antibiotic residues in cow's milk by the acidification test is shown in table 2 .

Of the 160 milk samples tested by the acidification test, 29 samples were positive $(18.12 \%)$ while the remaining 131 samples gave a negative result for all antibiotic residues sought $(81.87 \%)$. Only one sample was suspicious $(0.62 \%)$ $(P<0.05)$.

Table 2. Overall result obtained for the acidification test

\begin{tabular}{|c|c|c|c|c|c|c|c|}
\hline \multirow{2}{*}{ Region } & Number of & \multicolumn{7}{|c|}{ Results } \\
\cline { 3 - 9 } & samples & Positive & $\%$ & Negative & $\%$ & Suspicious & $\%$ \\
\hline Algiers & 48 & 10 & 20.80 & 37 & 77.08 & 1 & 2.08 \\
\hline Boumerdes & 112 & 19 & 16.96 & 93 & 83.03 & 0 & 0 \\
\hline Total & 160 & 29 & 18.12 & 131 & 81.87 & 1 & 0.62 \\
\hline
\end{tabular}




\section{Results of the test for antibiotic residues in cow's milk by the confirmatory test}

It should be remembered that we first checked the sensitivity of strains before starting the actual technique. Table 3 reports the averages of the positive results of the confirmatory agar diffusion test with both test microorganisms: $B$. strearothermophilus and B. subtilis.

A result considered positive shows a circular translucent inhibition zone around the disc impregnated with the tested milk having a diameter greater than or equal to $10 \mathrm{~mm}$. Of the 160 milk samples tested with the two strains of B. stearothermophilus and B. subtilis, 29 samples were positive.

\section{B. stearothermophilus}

In this study, 27 samples showed inhibition zones with a mean diameter greater than $12.07 \pm 2.34 \mathrm{~mm}$. These samples were considered positive for penicillin and/or tetracycline residues.

\section{B. subtilis}

Only 2 of the 29 tested samples showed inhibition zones with a mean diameter greater than $10.5 \pm 0.5 \mathrm{~mm}$. These samples were considered positive for macrolide and/or aminoside residues. In order to provide greater precision concerning the families of antibiotics detected, we presented the distribution of positive samples from each region in relation to each family of antibiotics tested.

\section{Results of the search for beta-lactam and/or tetracycline residues}

The distribution of samples that tested positive by the confirmatory agar diffusion test for each region in relation to beta-Lactamines and/or Tetracyclines is shown in Table 4.

Table 3. Average diameter of the inhibitions obtained by region and by test microorganism

\begin{tabular}{|c|c|c|c|c|}
\hline Region & $\begin{array}{l}\text { Number } \\
\text { of positive } \\
\text { samples }\end{array}$ & $\begin{array}{c}\text { Microorganism } \\
\text { test }\end{array}$ & $\begin{array}{c}\text { Mean of } \\
\text { inhibition } \\
\text { zone }(\mathrm{mm})\end{array}$ & $\begin{array}{c}\text { ATB } \\
\text { family } \\
\text { detected }\end{array}$ \\
\hline \multirow{4}{*}{ Algiers } & 2 & \multirow{9}{*}{$\begin{array}{l}\text { Bacillus } \\
\text { stearothermophilus }\end{array}$} & 12.00 & \multirow{10}{*}{$\begin{array}{c}\text { Penicillin } \\
\text { and /or } \\
\text { Tetracyclines }\end{array}$} \\
\hline & 4 & & 12.25 & \\
\hline & 3 & & 10.00 & \\
\hline & 1 & & 11.67 & \\
\hline \multirow{6}{*}{ Boumerdes } & 2 & & 11.00 & \\
\hline & 4 & & 12.57 & \\
\hline & 6 & & 11.33 & \\
\hline & 1 & & 13.17 & \\
\hline & \multirow{2}{*}{4} & & 14.67 & \\
\hline & & Mean 1 & 12.33 & \\
\hline \multirow{3}{*}{ Boumerdes } & 1 & \multirow{2}{*}{ Bacillus subtilis } & 10.00 & \multirow{4}{*}{$\begin{array}{l}\text { Aminosides } \\
\text { and/or } \\
\text { macrolides }\end{array}$} \\
\hline & \multirow{2}{*}{1} & & 11.00 & \\
\hline & & Mean 2 & 10.5 & \\
\hline Total & & Global mean & 11.28 & \\
\hline
\end{tabular}


Table 4. Result of the search for beta-lactamines and/or tetracycline residues

\begin{tabular}{|c|c|c|c|c|c|}
\hline \multirow{2}{*}{ Region } & Number of & \multicolumn{4}{|c|}{ Results } \\
\cline { 3 - 6 } & samples & Positive & $\%$ & Negative & $\%$ \\
\hline Algiers & 11 & 10 & 90.90 & 1 & 9.09 \\
\hline Boumerdes & 19 & 17 & 89.47 & 2 & 10.52 \\
\hline Total & 30 & 27 & 90 & 3 & 10 \\
\hline
\end{tabular}

Table 5. Result of the search for residues of macrolides and/or aminoglycosides

\begin{tabular}{|c|c|c|c|c|c|}
\hline \multirow{2}{*}{ Region } & \multirow{2}{*}{$\begin{array}{c}\text { Number of } \\
\text { samples }\end{array}$} & \multicolumn{5}{|c|}{ Results } \\
\cline { 3 - 6 } & Positive & $\%$ & Negative & $\%$ \\
\hline Algiers & 11 & 0 & 0 & 11 & 100 \\
\hline Boumerdes & 19 & 2 & 10.52 & 17 & 89.47 \\
\hline Total & 30 & 2 & 6.66 & 28 & 93.33 \\
\hline
\end{tabular}

Table 6. Overall result of the search for antibiotic residues

\begin{tabular}{|c|c|c|c|c|c|c|c|c|c|}
\hline \multirow{2}{*}{ Region } & \multirow{2}{*}{$\begin{array}{c}\text { Number of } \\
\text { Samples }\end{array}$} & \multicolumn{2}{|c|}{$\begin{array}{c}\text { Beta- } \\
\text { lactamines }\end{array}$} & \multicolumn{2}{c|}{ Tetracyclines } & \multicolumn{2}{c|}{ Macrolides } & \multicolumn{3}{c|}{ Aminosides } \\
\cline { 2 - 13 } & positive & $\%$ & positive & $\%$ & positive & $\%$ & positive & $\%$ \\
\hline Algiers & 48 & 4 & 8.33 & 6 & 12.5 & 0 & 0 & 0 & 0 \\
\hline Boumerdes & 112 & 7 & 6.25 & 11 & 9.82 & 2 & 1.78 & 0 & 0 \\
\hline Total & 160 & 11 & 6.87 & 17 & 10.62 & 2 & 1.25 & 0 & 0 \\
\hline
\end{tabular}

Of the 30 samples testing positive in the acidification test and the one suspicious sample:

\section{7 milk samples positive by the acidification test $(90 \%)$ were contaminated by beta-Lactamines and/or Tetracyclines residues. \\ - 2 milk samples positive by the acidification test $(10 \%)$ did not contain residues of beta- Lactamines and/or Tetracyclines $(P<0.05)$.}

\section{Results of the search for residues of macrolides and/or aminoglycosides}

The distribution of samples that tested positive by the confirmatory agar diffusion test for each region with respect to macrolides and/or aminoglycosides is shown in Table 5.

A positivity rate of $10.52 \%$ represented by two milk samples contaminated by residues of macrolides and/or aminosides was registered in the region of Boumerdes. On the other hand, in Algiers, no milk samples were contaminated with residues of macrolides and/or aminoglycosides.

In general, two milk samples revealed positive by the acidification test (6.66\%) presented residues of macrolides and/ or aminoglycosides. Moreover, 28 milk samples $(93.33 \%)$ that were positive in the acidification test did not contain residues of macrolides and/or aminoglycosides $(P<0.05)$. 


\section{Overall results of the search for antibiotic residues by family in cow's milk}

The overall results of the search for antibiotic residues are presented in Table 6 .

We observed that of the 160 cow's milk samples tested, 11 were contaminated with beta-lactam residues $(6.87 \%), 17$ were contaminated with tetracycline residues $(10.62 \%)$, and only 2 were contaminated with macrolide residues $(1.25 \%)$. No samples were contaminated with aminoglycoside residues $(P<0.05)$.

\section{Discussion}

Milk and dairy products occupy an important place in the diet of every Algerian citizen. In Algeria, issues caused by antibiotic residues are to be feared since the quantities of fresh milk reserved for processing are still insufficient to allow the rejection of milk containing antibiotic residues (Ouslimani, 2008). Testing for residues using the acidification test allowed for an initial screening of all cow's milk samples, while the agar diffusion test allowed for confirmation of positivity of samples by identifying the families of antibiotics and removing any ambiguity concerning suspicious samples.

In general, this study showed the contamination of 31 samples of cow's milk with antibiotic residues of the 160 samples analysed by the acidification test, giving a contamination rate of $19.37 \%$. However, our results differed from those reported elsewhere, though testing also differed. For example, Lebres and Mouffok (1989) tested 136 samples of farmed raw milk revealed a positivity rate of $25 \%$ using the official method, while Ouertani (2003) reported a positivity rate of $40 \%$ for milk samples tested using Delvotest SP in Tunisia; and Siousarran (2003) tested the yoghurt of six milk samples taken from the delivery bay of the dairies in Niger showed a positivity rate of $67 \%$. These contaminations were due to a range of causes, including the excessive use of antibiotics as a curative measure to eradicate the infection, avoid animal mortality and restore production; n-compliance with the waiting period, which is often shortened, either through ignorance or intentionally to discard as little milk as possible, and non-compliance with dosages (increase/decrease in doses and/or rate of administration), as a lack of awareness that any change in treatment protocols leads to a change in waiting times.

In this current work, the results obtained after confirmation with the agar diffusion test are similar to those reported by Kress et al. (2005) on 63 positive raw milk samples presenting a positivity of $95 \%$ for beta-lactam. Several surveys by many researchers have found that the most commonly used antibiotics in dairy cattle farming are beta-lactamines and tetracyclines.

Beta-lactam antibiotics are still the most active, least toxic and most clinically used antibiotics, which explain the high risk of contamination of milk by these molecules and the choice of the specific test dairy for this antibiotic (Reybroeck, 2010). Antibiotics used in animal therapy are sometimes incriminated in human allergology. Among the antibiotics most often incriminated are penicillins belonging to the beta-lactam family. These molecules used in human medicine are involved in the majority of drug allergies cases. The presence of penicillin in milk could cause sensitization of the human population and trigger symptoms of allergic shock in sensitized subjects (Jepsen, 1950). A case cited by Borrie and Barrett (1961) proved that the absorption of milk containing penicillin can cause recurrent eczematous eruptions in sensitized persons. The patient cited reacted strongly to a dose of 15 units per day, i.e. $500 \mathrm{~mL}$ milk containing 0.03 units of penicillin per millilitre. 
Due to their broad spectrum of activity, low toxicity and good tissue diffusion, tetracyclines have the advantage that they can be used against various diseases and many bacterial species. Despite the age of tetracyclines, they are still among the most widely used antibiotics in veterinary medicine and, due to their relatively long waiting time in milk, the probability of finding tetracyclines in raw milk is high (Larpent and Sanglier, 1989; Yala et al., 2001; Tarzaali et al., 2008; Reybroeck, 2010).

Our results showed that of the total of 160 raw milk samples analysed, 130 samples were negative (81.25\%). A high rate of negative milk does not necessarily mean that it is safe, because it is possible for milk to contain antibiotic residues at concentrations below the detection limit of the test determined by the maximum residue limit, or contain antibiotic residues that are not expressed in the test giving rise to false negative results. This is the case with polypeptides and chloramphenicol, although the latter is prohibited in livestock (Ouslimani, 2008).

In the present study, we preheated milk samples in a water bath at $80^{\circ} \mathrm{C}$ for 5 minutes prior to testing to eliminate natural inhibitors. This preheating can destroy certain antibiotics known to be heat-sensitive, such as the neomycin, kanamycin and chlortetracycline in a proportion of $50 \%$ to $60 \%$ (Billon and Seng Huuor, 1979). Furthermore, poor preservation of the sample may allow for growth of contaminating flora, which may cause acidification of milk or destruction of certain antibiotics (i.e., keeping a sample for 90 minutes at room temperature in the laboratory may reduce the detection rate of penicillin by $50 \%$ in milk supplemented with 0.005 and 0.01 IU of this molecule; Brouillet, 1994; 2002).

In this study, only one milk sample was considered suspicious in the first acidification test. In order to decide on this result, it was necessary to pass this sample through the second confirmatory test which revealed the absence of any antibiotic residues. It should be noted that the microbiological method is characterized by a threshold of detection of antibiotic residues as close as possible to the Maximum Residue Limits of the antibiotics most commonly used in the treatment of dairy cattle (Ouslimani, 2008).

The sensitivity of the acidification test is better for both families of antibiotics most widely found in the intramammary specialties used in Algeria (beta-lactamine and tetracycline). The growth of $B$. stearothermophilus is inhibited according to Heeschen and Blüthgen (1991) at a concentration of $5 \mathrm{ppb}$ ampicillin. The confirmatory assay shows a high specificity (Fabre et al., 2002).

Under Algerian legislation, it is mandatory to test for antibiotic residues in raw milk (JORA N³5 of 25 May 1998) to ensure product safety by respecting the maximum residue limits set by regulations, and to ensure milk suitable for processing. Despite this regulation, it is not always systematically applied by some dairies less concerned about the risks of antibiotic residues.

\section{Conclusions}

Veterinary drugs, particularly antibiotics, are part of the therapeutic arsenal that is indispensable in today's livestock farming, as they help to prevent or treat a large number of infectious diseases. These antibiotics can be found in the form of residues in milk and dairy products of treated cows. The dangers associated with the presence of these residues are toxicological, carcinogenic and allergic, and the appearance of antibiotic-resistant pathogenic bacterial strains in addition to the harmful effects in the dairy industry.

The present study highlighted the contamination of milk by antibiotic 
residues such as beta-lactam, tetracyclines, and macrolides, which constitute a significant risk in cases of allergies and the development of antibiotic resistance in consumers. The responsibility is on the farmer administering the medication, and on the veterinarian who plays a central role in the control of antibiotic use in animal health. The veterinarian is involved in the design, development and marketing authorization of the veterinary antibiotic drug, but also and above all in its distribution, administration and control of good practices in its use.

At the end, it is necessary to raise the issue of antibiotic resistance and antibiotic residues, which are becoming a major problem day by day, hence the need to work hard to preserve these precious molecules.

\section{References}

1. BEN-MAHDI, M. H. and S. OUSLIMANI (2009): Mise en évidence de résidus d'antibiotiques dans le lait de vache produit dans l'Algérois. Eur. J. Sci. Res. 36, 357-362.

2. BILLON, J. and T. A. O. SENG HUUOR (1979): Détection des antibiotiques, identification et dosage par la méthode éléctrophorétique. Le Lait 587, 361375.

3. BORRIE, P. and L. BARETT (1961): Médicaments veterinaries et sécurité alimentaires, aspects analytiques du problem des résidus. Brit. Med. J. $2,1267$.

4. BROUILLET, P. (1994): Maîtrise de la présence d'inhibiteurs dans le lait. Rec. Méd. Vét. 170, 443454 .

5. BROUILLET, P. (2002): Résidus de médicaments dans le lait et tests de détection. Bulletin des GVT, $15,25-41$.

6. DEWDNEY, J. M. L., M. P. RAYNAUD, F. BLANC, J. P. SCHEID, T. JACKSON, S. LENS and C.VERSCHUEREN (1991): Risk assessment of antibiotic residues of $\beta$-lactams and macrolides in food, products with regard to their immunoallergic potential. Food Chem. Toxicol. 29, 477-483.

7. FABRE, J. M., J. P. MORETAIN and X. BERTHELOT (2002): Evolution de la méthode interprofessionnelle de recherche des résidus d'antibiotiques dans le lait. Bull. Group. Tech. Vét. 15, 172-178.

8. HEESCHEN, W. H. and A. BLÜTHGEN (1991): Veterinary drugs and pharmacologically active compounds. In: Residues and contaminants in milk products. IDF Special Issue. Brussels, Belgium: International Dairy Federation 9101, 16-39.
9. JEPSEN, A. (1950): Les résidus de désinfectatns et d'antibiotiques dans le lait. Nord. Vet. Med. 2, 447.

10. KRESS, C., C. SEIDLER, B. KERP, E. SCHNEIDER and E.USLEBER (2005): Experiences with an identification program for inhibitor-positive milk samples. Anal. Chim. Acta 586, 275-279.

11. LARPENT, J. P. (2013): Microbiologie alimentaire : technique de laboratoire. Technique et documentation. Ed. Lavoisier, Paris, 1073 p.

12. LARPENT, J. P. and J. J. SANGLIER (1989): Biotechnologie des antibiotiques. Edition: Masson. P 7-9.

13. LEBRES, E. and F. MOUFFOK (1989): Recherche d'antibiotique et de résidus d'antibiotiques dans les laits. Maghreb vétérinaire 17, 5-7.

14. MAHMOUDI, R., R. ASADPOUR, M. R. PAJOHI ALAMOTI, A. GOLCHIN, R. KIYANI, R. MOHAMMAD POUR and K. ALTAFY (2013): Raw cow milk quality: Relationship between antibiotic residue and somatic cell count. Int. Food Res. J. 20, 3347-3350.

15. MENSAH, S. E. P., A. B. ABOH, S. SALIFOU, G. A. MENSAH, P. SANDERS, F. A. ABIOLA and O. D. KOUDANDE (2014): Risques dus aux résidus d'antibiotiques détectés dans le lait de vache produit dans le Centre Bénin. J. Appl. Biosci. 80, $7102-7112$.

16. OUERTANI, H. (2003): Les résidus d'antibiotiques dans le lait: Enquête dans le un centre de collecte de la région de Béja, Thèse Doc. Vét., Ecole Nationale de Médecine Vétérinaire, Sidi Thabet, $54 \mathrm{p}$.

17. OUSLIMANI, S. (2008): Contribution à l'étude des résidus d'antimicrobiens dans le lait cru produit dans l'Algérois. Thèse de magister soutenue publiquement à l'ENSV.

18. PERRY, K., J. D. TONEY and A. L. LEBLANC (1967): Effect of nitrofurantoin on the human fetus. Tex. Rep. Biol. Med. 25, 270-272.

19. PERSOONS, D. (2011): Antimicrobial use and resistance in Belgian broiler production. $\mathrm{PhD}$ thesis, Ghent University, Belgium.

20. PILET, C. and B. TOMA (1969): Etude de la thermostabilité de quelques antibiotiques. J. Dairy Sci. 145, 899-909.

21. PLEADIN, J. and M. SAMARDŽIJA (2019): Hormonally active substances in the food chain from farm animals to consumers. Vet. stn. 50, 501512.

22. REYBROECK, W. (2010): Screening for residues of antibiotics and chemotherapeutics in milk and honey. Doctorat thesis. Faculteit Diergeneeskunde Universiteit Gent, 295 p.

23. SACHI, S., J. FERDOUS, M. H. SIKDER, S. M. AZIZUL and K. HUSSANI (2019): Antibiotic residues in milk: Past, present, and future. J. Adv. Vet. Anim. Res. 6, 315-332.

24. SIOUSARRAN, V. (2003): Hygiène du lait cru en zone urbaine et périurbaine de Niamey, Niger. Rapport de stage, pp. 42-43.

25. TARZAALI, D., A. DECHICHA, S. GHARBI, M. K. BOUAISSA, N. YAMNAINE and D. 
GUETARNI (2008): Recherche des résidus des tétracyclines et des bêta-lactamines dans le lait cru par le MRL Test (ROSA TEST) à Blida, Algérie. In : 6èmes Journées Scientifiques Vétérinaires sur le médicament vétérinaire : nouvelles approches thérapeutiques et impact sur la santé publique. ENSV Algérie 23-24.

26. YALA, D., A. S. MERAD, D. MOHAMEDI and M. N. OUAR KORICH (2001): Classification et Mode d'action des antibiotiques. Médecine du Maghreb 91.

\section{Rezidue antibiotika u kravljem mlijeku}

Nora MIMOUNE, National high school of veterinary medicine, Algiers, Bab-Ezzouar, Algeria, Institute of Veterinary Sciences, LBRA Laboratory, University of Blida 1, Algeria; Sara SEDDIKI, Faculty of Natural and Life Sciences and Earth and Universe Sciences, Mohamed El Bachir El Ibrahimi University, Bordj Bou Arréridj, Algeria; Ratiba BAAZIZI, Imad Eddine SABOUNDJI, Djamel KHELEF, National high school of veterinary medicine, Algiers, Bab-Ezzouar, Algeria; Radhwane SAIDI, Department of Agronomic Sciences, Faculty of Sciences, Laboratory of Biological and Agronomic Sciences, University of Laghouat, Algeria; Rachid KAIDI, Institute of Veterinary Sciences, LBRA Laboratory, University of Blida 1, Algeria

Veterinarski lijekovi, uglavnom antibiotici, koji se rabe u terapeutske i profilaktičke svrhe u mliječnih krava, mogu biti uzrok prisutnosti njihovih rezidua $u$ mlijeku, a to može imati štetne posljedice po zdravlje životinja i ljudi. Da bismo u potpunosti razumjeli ovaj problem ova studija ima za cilj procijeniti prisutnost rezidua antibiotika u 160 uzoraka kravljeg mlijeka u sjevernom središtu Alžira, uporabom dviju različitih mikrobioloških tehnika: pokusom acidifikacije i testom difuzije $\mathrm{u}$ agaru, s dva soja Bacillus stearothermophilus i Bacillus subtilis. Dobiveni rezultati pokazali su kontaminaciju rezida antibiotika u 18,12\% prikupljenih uzoraka. Ostatci tetraciklina i/ili penicilina bili su odgovorni za onečišćenje 90 $\%$ pozitivnih uzoraka mlijeka, dok su rezidue makrolida i/ili aminoglikozida otkrivene $\mathrm{u}$ tek $6,66 \%$ pozitivnih uzoraka. Potvrda testom difuzije u agaru 31 uzorka sirovog mlijeka uključujući 30 pozitivnih i jedan upitni, analizirani pokusom acidifikacije, pokazali su postotak onečišćenja od 90,32 \% za betalaktame i/ili tretracikline (28 uzoraka) i stopu onečišćenja od $3,22 \%$ za aminoglikozide i/ ili makrolide (2 uzorka). Upitni se uzorak pokazao negativnim $u$ testiranju. Rezultati ovog rada pokazali su da su kontrola i nadzor antibiotika i njihovih rezidua $\mathrm{u}$ hrani životinjskog podrijetla posebno važni da bi se osigurala sigurnost hrane životinjskog podrijetla, a time zaštitili potrošači.

Ključne riječi: rezidue, antibiotik, mlijeko, krava, pokus acidifikacije, test difuzije u agaru 